\title{
Community structure of Coleoptera in Bethuadahari Wildlife Sanctuary, West Bengal, India
}

\author{
Paramita Basu, ${ }^{1}$ Gautam Aditya $^{2}$ \& A. K. Sanyal ${ }^{1,3}$ \\ ${ }^{1}$ Zoological Survey of India, M-Block, New Alipore, Kolkata 700053, India \\ ${ }^{2}$ Department of Zoology, University of Calcutta, 35 Ballygunge Circular Road, Kolkata 700019, India \\ ${ }^{3}$ Corresponding author. E-mail: asokzsi@yahoo.co.in
}

\begin{abstract}
We focused on the coleopteran species assemblage in a tropical deciduous forest in the Bethuadahari Wildlife Sanctuary, West Bengal, India. During a 2-year survey, we collected 56 species belonging to 13 families of Coleoptera, in varying relative abundance. Among the species, 15 belong to the family Chrysomelidae, nine to the Staphyllinidae, and four to the Coccinellidae. Our results substantiate the importance of the Bethuadahari Wildlife Sanctuary for the conservation of coleopteran insects.
\end{abstract}

Key words. Species assemblage; species inventory; Insecta.

\section{INTRODUCTION}

Insects are distributed worldwide in all habitats and constitute about half of the global diversity of animals (GULLAN \& Cranston 1994, Gillott 2005). A majority of insect species are beetles, grouped under the order Coleoptera. Of coleopterans, there are about 15,500 described species (nearly $4.5 \%$ of the world fauna) recorded from India to date, being with 3,100 endemic for the country (RAMKRISHNA \& ALFRED 2007). Ecosystems are dominated by beetle species with diverse morphologies that correspond to their functional roles within the ecosystem. In almost all habitat types, the richness and abundance of beetles are being explored worldwide, including beetle assemblages associated with agroecosystems (BAMBARADENIYA et al. 2004, Petrova et al. 2006, Kumar et al. 2009), as well as forests and protected areas (HALME \& NiEMELÄ 1993, CHUNG et al. 2000, LUCKY et al. 2002, APIGIAN et al. 2006, Joshi et al. 2008, GrimbaCher \& STORK 2009, SABU et al. 2011, CHANDRA \& Gupta 2012, Thakare \& Zade 2012, CAMpos \& HernánDEZ 2013). By assessment of beetle species assemblages, the functional role of beetles in their respective ecosystems can be better understood.

Tropical forests, with ample resources and hospitable habitats, provide an ideal ecosystem for coleopterans (BASSET et al. 2003). In comparison to the similar ecosystems, the functions of the forest ecosystems are in part dependent on the foraging (Mattson \& Addy 1975, Brown 1985, Schowalter 1995) and litter processing (PFEIFFER 1996, NAIR 2007) by the beetles and other insects. The beetles represent the single major group of insects that explore both live and dead plant parts thereby accounting for the dynamic nature of the flow of energy and matter in the ecosystem concerned (LOSEY \& VAUGHAN 2006, 2008). Appraisal of the beetle assemblages in forest ecosystems is being emphasized in several studies spanning different geographical areas and suggests their dominance over other insect orders (Schowalter et al. 1986, Novotny \& BASSET 2005). Our study is an account of the diversity of Coleoptera in the tropical moist deciduous forest of Bethuadahari Wildlife Sanctuary, West Bengal, India, and highlights the need for conservation planning and management in the reserve. Keeping in view the significance of the beetles in forest ecosystems, the information of the present study may be utilized for their conservation and maintaining the forest as a reserve area.

\section{MATERIALS AND METHODS}

\section{Study area}

The 66.77 ha Bethuadahari Wildlife Sanctuary (BWS; $23^{\circ} 35^{\prime} \mathrm{N}$, $088^{\circ} 23^{\prime} \mathrm{E}$; $5 \mathrm{~m}$ above sea level) is located in the Nadia district of West Bengal, India (Fig. 1). The wildlife sanctuary now supports a tropical moist deciduous forest, but previously it was degraded and planted forest. The wildlife sanctuary was declared as such on 19 August 1998, under the Notification No. of 2772 of the Department of Forest, Government of West Bengal, India.

The upper canopy of the forest comprised of Teak (Tectona grandis Linn. F.), Arjun (Terminalia arjuna (Roxb.)), Siris (Albizia lebbeck (L.) Benth.), Sissoo (Delbergia sissoo Roxb.), Sal (Shorea robusta Gaertn.), Mahogany (Swietenia macrophyla King), and Ficus (Ficus spp.), while the middle and lower canopies are less demarcated. Trees such as Jamun (Syzigium cumini), Minjiri (Cassia sp.), Bael (Aegle marmelos (Linn)), Atha (Annona squamosa Linn), and Hamjam (Polyalthia suberosa (Roxb.)), comprise the middle and lower canopy. The shrubs Cassia tora Linn, Ageratum sp., and Polygonum spp., as well as various species of Colocasia, dominate the ground vegetation. There are also sparse grasses such as Imperata sp. (Ulloo grass), Paspalum sp., Panicum sp., Cynodon sp., and Brachiaria sp. that form a mosaic of green patches and 


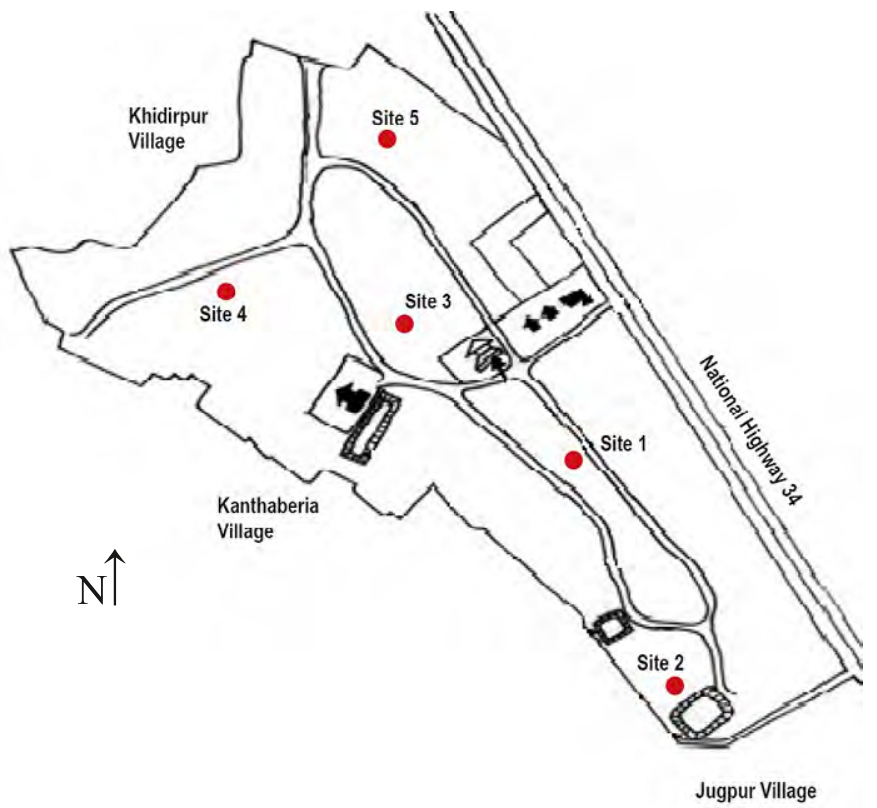

Figure 1. Map of Bethuadahari Wildlife Sanctuary, West Bengal, India, with the sampling plots denoted by red dots.

open soil.

\section{Data collection and analysis}

To collect coleopterans, we employed the quadrat method (Brower et al. 1998, KreBs 1999), following the random selection of five survey plots in various parts of the forest. Each plot constituting an area of $625 \mathrm{~m}^{2}\left(25 \times 25 \mathrm{~m}^{2}\right)$ which were separated one from another by at least a distance of $200 \mathrm{~m}$. The plots consisted of a heterogeneous mixture of grass and barren soil as well as shrubs and trees. Within each plot, three quadrats, each $5 \times 5 \mathrm{~m}^{2}$ were randomly selected, in compliance with the norms of interspersion and randomization such that the samples represent true replicates (HURLBERT 1984).

In each quadrat, we used sweep netting, pitfall trapping, fluorescent light trapping, and hand picking with a net to capture beetles. Different collection methods were employed to ensure that most species were captured. The sweep net used was $30 \mathrm{~cm}$ in diameter, $90 \mathrm{~cm}$ deep, and with $1.5 \mathrm{~mm}$ mesh. Each sweep represented a horizontal swing 0.5 to $2 \mathrm{~m}$ above the ground and with an arc between $135^{\circ}$ to $180^{\circ}$ (against the horizontal plane). At each quadrat, 100 random sweeps were made. One pitfall trap was placed at the center of each quadrat and left for $24 \mathrm{~h}$. These were transparent plastic jars $(10 \times 10$ $\mathrm{cm}), 1 / 3$ filled with a 2:1 solution of propylene glycol in water (Halme \& Niemelä 1993, Taboada et al. 2010, Earnst \& BUdDLE 2013). A light trap was set up at the center of each plot for $10 \mathrm{~h}$ (18:00-4:00 h) (LeE et al. 2008). Therefore, beetles collected from each plot comprised of cumulative collections by 3 light trap, 3 pitfall traps, and 3 sweep net samples. Additional collections by hand picking was also employed to include insects directly observed within the quadrat. The hand picking method used a $15 \mathrm{~cm}$ net, with each search lasting 15 min each. Consequently, we collected 45 samples from the 5 plots at each sampling operation involving all the methods. Twenty-four sampling operations were carried out, 1 in each month, from January 2010 to December 2011.

Collected insects were placed in plastic bags or specimen containers and brought to the laboratory in Zoological Survey of India (ZSI), Kolkata. Specimens were separated into families using Crowson (1956) and ChOATE (1999), and mainly the numerous volumes on Coleoptera in the Fauna of British India, including Ceylon and Burma (GAHAN 1906, JACOBY 1908, Fowler 1912, Marshall 1916, Maulik 1919, 1926, 1936, ANdrewes 1929, 1935, CAMERon 1930, 1932, 1934, 1939a, 1939b). Identifications of genera or species were made with the help of the Scientists of the Coleoptera section in the Zoological Survey of India (ZSI), Kolkata. Specimens were deposited in the ZSI (Kolkata).

The data on the relative abundance of each species was used for diversity analysis using BDPro software (MCALEECE et al. 1997). In order to estimate the diversity indices, raw data of each species collected from the plots were pooled together into 24 monthly samples. Using relative abundance as a measure, a discriminant function analysis (MANLY 1994, LEGENDRE \& LEGENDRE 1998) was performed to show differences between families of Coleoptera.

\section{RESULTS}

The 2-year survey of the forest revealed the presence of at least 56 species of coleopterans belonging to 13 families (Tables 1 and 2). Among the families, Chrysomelidae, Cerambycidae, Brentidae, and were the phytophagous groups (WeIss 1922, SARooshi et al. 1979, Silfyerberg 1989). With 16 species found, Chrysomelidae was the most abundant and species-rich family. Beetles that prey on macro-invertebrates and vertebrates (Weiss 1922, Dixon 2000, Omkar \& Pervez 2000) were represented by 18 species belonging to the families Carabidae, Coccinellidae, Lampyridae, Lycidae, Dytiscidae, and Hydrophilidae. There were 16 saprophagous species belonging to 4 families, Scarabaeidae (dung beetles), Staphylinidae (rove beetles), Tenebrionidae (darkling beetlea), and Elateridae

Table 1. Representative families of Coleoptera with ascertained species numbers observed in course of sampling of the Bethuadahari Wildlife Sanctuary, West Bengal, India, during 2010-2011.

\begin{tabular}{lc}
\hline Family & Number of species \\
\hline Phytophagous (about 38\%) & 16 \\
Chrysomelidae & 2 \\
Cerambycidae & 2 \\
Curculionidae & 2 \\
Brentidae & \\
\hline Predaceous (about 33\%) & 6 \\
Coccinellidae & 1 \\
Lampyridae & 1 \\
Lycidae & 2 \\
Hydrophilidae & 4 \\
Dytiscidae & 4 \\
Carabidae & \\
\hline Saprophagous (about 30\%) & 3 \\
Scarabaeidae & 2 \\
Tenebrionidae & 2 \\
Elateridae & 9 \\
Staphylinidae & \\
\hline
\end{tabular}


Table 2. Species of Coleoptera recorded from Bethuadahari Wildlife Sanctuary, West Bengal, India $\left(\mathrm{n}_{\mathrm{i}}\right.$ represents relative proportion of the species collected in the total sample; description of 56 species given).

\begin{tabular}{|c|c|c|c|}
\hline Species name & $\mathbf{n}_{\mathbf{i}}$ & Voucher no. & Characters \\
\hline Family Chrysomelidae & & & $\begin{array}{l}\text { Antennae not longer than body; not inserted on frontal prominence; tibial spurs } \\
\text { absent }\end{array}$ \\
\hline Altica unicolor (Olivier, 1808) & 0.0005 & ZSI/5510/17 & Possession of a femoral spring mechanism \\
\hline Phygasia sp. & 0.005 & ZSI/5511/17 & Elytra bicolor. Intermediate antennal segments thickened in male \\
\hline Monolepta signata (Olivier, 1808) & 0.0057 & $\mathrm{ZSI} / 5512 / 17$ & $\begin{array}{l}\text { Elytra black, each elytron with two yellow stains; head, pronotum, legs and abdomi- } \\
\text { nal sternites; reddish-brown }\end{array}$ \\
\hline Monolepta bifasciata (Hornstedt, 1788) & 0.0714 & ZSI/5513/17 & Body shining pale yellow with two dark red spot on each elytron \\
\hline Monolepta limbata (Olivier, 1808) & 0.0057 & ZSI/5514/17 & $\begin{array}{l}\text { Body pale brown; elytra, epipleuron, humerous, and scutellum rounded by black } \\
\text { border }\end{array}$ \\
\hline Monolepta sp. & 0.0025 & ZSI/5515/17 & Body brownish yellow with black antennae \\
\hline Aloria sp. & 0.002 & ZSI/5516/17 & Body metallic blue with labrum, antennae, tibiae and tarsi blackish \\
\hline Phaedon sp. & 0.0042 & ZSI/5517/17 & Head small, deeply inserted into prothorax; pronotum with coarse punctures \\
\hline Oides flava (Olivier, 1807) & 0.0063 & ZSI/5518/17 & Dorsally brown; metasternum and abdominal sternites black \\
\hline Galerucella placida Baly, 1878 & 0.0035 & ZSI/5519/17 & $\begin{array}{l}\text { Dorsally dark brown; antenna, apical area on head, scutellum, ventral side and legs } \\
\text { black }\end{array}$ \\
\hline Calomicrus flavovittis Motschulsky, 1858 & 0.0037 & $\mathrm{ZSI} / 5520 / 17$ & $\begin{array}{l}\text { Body shining brown with blackish brown longitudinal stripe on each elytron from } \\
\text { humerus towards the apex }\end{array}$ \\
\hline Aphthona sp. & 0.0035 & ZSI/5521/17 & Strongly developed hind femora \\
\hline Hoplasoma unicolor (Illiger, 1800) & 0.009 & ZSI/5522/17 & $\begin{array}{l}\text { Yellowish brown shining coloration; elytra with subregular punctation and without } \\
\text { carinae on disc }\end{array}$ \\
\hline Sphenoraia bicolor (Hope, 1831) & 0.0023 & ZSI/5523/17 & Body dark brown with seven black spots on each elytron \\
\hline Aspidomorpha dorsata (Fabricius, 1787) & 0.0018 & ZSI/5524/17 & Body rounded with smooth elytra \\
\hline Caryedon sp. & 0.001 & ZSI/5525/17 & Pronotum wider at base; pronotal carina absent in front \\
\hline Family Coccinellidae & & & $\begin{array}{l}\text { Tarsal claws toothed or appendiculate; first ventral abdominal segment with } \\
\text { distinct curved coxal lines }\end{array}$ \\
\hline Coccinella transversalis Fabricius, 1781 & 0.0107 & ZSI/5526/17 & $\begin{array}{l}\text { Triangular black stain on the sub-humeral area of elytra followed by a wavy, black } \\
\text { post-median band }\end{array}$ \\
\hline Cheilomenes sexmaculata (Fabricius, 1781) & 0.0065 & $\mathrm{ZSI} / 5527 / 17$ & Each elytron with three zigzag transversal stripes \\
\hline Illeis indica Timberlake, 1943 & 0.0115 & ZSI/5528/17 & Eyes large, distance between eyes as wide as an eye or less; mandibles finely serrate \\
\hline Stethorus sp. & 0.0123 & ZSI/5529/17 & $\begin{array}{l}\text { Body black; prosternum broadly rounded anteriorly and without longitudinal } \\
\text { carinae }\end{array}$ \\
\hline Sticholotis sp. & 0.0118 & ZSI/5530/17 & Pronotum black; prosternum enlarged and concealing mouth parts entirely \\
\hline Rodolia sp. & 0.0073 & ZSI/5531/17 & Pubescence slightly yellowish and moderately dense; absence of elytral punctations \\
\hline Family Lampyridae & & & Metathorax epimeron long; many species with glowing organ \\
\hline Luciola sp. & 0.0068 & ZSI/5532/17 & Posterior angles of the pronotum acute and backwardly pointed \\
\hline Family Lycidae & & & Middle coxae distant; epipleura absent; elytra reticulated \\
\hline Lycostomus sp. & 0.0183 & ZSI/5534/17 & Reddish brown coloration with one black spot at the end of each elytron \\
\hline Family Scarabaeidae & & & Antennae with lamellate club and the plates composing antennal club flattened \\
\hline Apogonia sp. & 0.009 & ZSI/5533/17 & $\begin{array}{l}\text { Light brown colour with deep puctuation, emarginated clypeus, elytra elevated } \\
\text { along the sutures }\end{array}$ \\
\hline Onthophagus sp. & 0.0128 & ZSI/5535/17 & $\begin{array}{l}\text { Presence of punctation in pronotum; clypeal margin tridentated; dorsal surface } \\
\text { glabrous }\end{array}$ \\
\hline Anomala sp. & 0.0323 & ZSI/5536/17 & Mesosternum without intercoxal process \\
\hline Family Hydrophilidae & & & $\begin{array}{l}\text { Hind tarsi clearly } 5 \text { segmented; maxillary palpi as long as or longer than antennae; } \\
\text { antennae with terminal 3-4 segments forming a distinct club }\end{array}$ \\
\hline Berosus fairmairei Zaitzev, 1908 & 0.01 & ZSI/5537/17 & elytra with apical spine and the upper surface malted \\
\hline Coelostoma sp. & 0.0085 & ZSI/5538/17 & Antennal club very long and nine jointed, not carinate \\
\hline Family Brentidae & & & $\begin{array}{l}\text { Antennae straight, without distinct club; beak present at least in female and point- } \\
\text { ing directly forward }\end{array}$ \\
\hline Apion sp. & 0.0974 & ZSI/5539/17 & Elytra unicolor, entirely brown; body length $3.5-4 \mathrm{~mm}$ \\
\hline Alocentron curvirostre(Gyllenhal, 1833) & 0.0451 & ZSI/5540/17 & Rostrum arched, with deep longitudinal ventral fovea; pronotum campanulate \\
\hline Family Curculionidae & & & Antennae short with broad club; eyes oval, emarginated, or divided \\
\hline Xylosandrus sp. & 0.0172 & ZSI/5541/17 & Smaller species with widely separated procoxae \\
\hline Hypothenemus sp. & 0.0025 & ZSI/5542/17 & Elytral striae marked by comparatively small punctures; frons convex \\
\hline Family Dytiscidae & & & $\begin{array}{l}\text { Hind legs modified for swimming, posterior margin with fringes of hairs; scutellum } \\
\text { visible }\end{array}$ \\
\hline Hydrovatus sp. & 0.011 & ZSI/5543/17 & Elytra ferruginous with profound punctation in elytra and metacoxae \\
\hline Hydroglyphus sp. & 0.011 & ZSI/5544/17 & Elytra without spine at apex and with lateral pale stripe \\
\hline Copelatus freudei Guignot, 1955 & 0.007 & ZSI/5545/17 & Hind coxal lines touching median line; sides of pronotum distinctly margined \\
\hline Laccophilus sp. & 0.008 & ZSI/5546/17 & Punctation on elytra uniform; presence of single tarsal claw in posterior legs \\
\hline Family Carabidae & & & Antennae moniliform; eyes not divided by lateral margin of head \\
\hline Cicindela sp. & 0.008 & ZSI/5547/17 & Antennae long, filiform; elytra black \\
\hline Coptodera sp. & 0.006 & ZSI/5548/17 & Body dark-brown; each elytron with three yellowish orange patches \\
\hline
\end{tabular}


Table 2. Continued.

\begin{tabular}{|c|c|c|c|}
\hline Species name & $\mathbf{n}_{\mathbf{i}}$ & Voucher no. & Characters \\
\hline Clivina sp. & 0.021 & ZSI/5550/17 & $\begin{array}{l}\text { Large body size greater than } 5 \mathrm{~mm} \text {; last visible abdominal segment without any } \\
\text { projection; tips of apical segment of maxillary palpi not finely produced }\end{array}$ \\
\hline Colliuris sp. & 0.06 & ZSI/5551/17 & $\begin{array}{l}\text { Pronotum narrow, longer than wide; elytron with apex truncate, exposing last } \\
\text { abdominal tergite }\end{array}$ \\
\hline Family Tenebrionidae & & & $\begin{array}{l}\text { Tarsal claws simples; front of head with protruding margin extending between the } \\
\text { eyes }\end{array}$ \\
\hline Gonocephalum sp. & 0.029 & ZSI/5552/17 & Large body, with head, pronotum, and elytra strongly depressed \\
\hline Scleron sp. & 0.055 & ZSI/5553/17 & Larger in size; pronotum and elytra strongly tuberculated \\
\hline Family Elateridae & & & Prothorax firmly joined to mesothorax; antennae inserted under margin of front \\
\hline Agrypnus sp. & 0.077 & ZSI/5554/17 & $\begin{array}{l}\text { Scutellum simples, pentagonal, with dense punctation and without longitudinal } \\
\text { carina }\end{array}$ \\
\hline Aeoloderma sp. & 0.045 & ZSI/5555/17 & $\begin{array}{l}\text { Frons convex, rarely flat, rounded anteriorly, rarely truncated, base usually with fine } \\
\text { longitudinally raised carina }\end{array}$ \\
\hline Family Staphylinidae & & & Elytra very short, dorsally exposing 4-7 abdominal segments \\
\hline Bledius sp. & 0.059 & ZSI/5556/17 & Presence of small well defined pit in prosternum \\
\hline Acanthoglossa brachycera Kraatz, 1859 & 0.002 & ZSI/5557/17 & Head and thorax with reticulate, umbilicate sculpture \\
\hline Stenus sp. & 0.054 & ZSI/5558/17 & Eyes very large; seventh abdominal segment with a short spine \\
\hline Astenus sp. & 0.005 & ZSI/5559/17 & Last antennal segment longer than 10th segment \\
\hline Philonthus sp. & 0.004 & ZSI/5560/17 & The suture and apical margin of elytra broadly reddish yellow \\
\hline $\begin{array}{l}\text { Dibelonetes bengalensis Biswas \& Sengupta, } \\
1980\end{array}$ & 0.004 & ZSI/5561/17 & Posterior margin of elytra broadly ferruginous red \\
\hline Cryptobium sp. & 0.008 & ZSI/5562/17 & Antennae geniculate; elytra entirely red \\
\hline Lathrobium unicolor Kraatz, 1859 & 0.003 & ZSI/5563/17 & Species reddish and testaceous; strong punctation in front of head \\
\hline Paederus fuscipes Curtis, 1826 & 0.005 & ZSI/5564/17 & Head dark blue; anterior femora entirely testaceous \\
\hline Family Cerambycidae & & & $\begin{array}{l}\text { Body elongate; antennae frequently longer than body, inserted on frontal promi- } \\
\text { nence; tibial spurs well developed }\end{array}$ \\
\hline Batocera sp. & 0.003 & ZSI/5565/17 & Large body size with greyish black coloration; antennae long \\
\hline Mesosa sp. & 0.017 & ZSI/5566/17 & $\begin{array}{l}\text { Antennae filiform, unarmed and short, extend beyond elytral apices; lateral margins } \\
\text { of pronotum without spines }\end{array}$ \\
\hline
\end{tabular}

(click beetles) (ChITTENDEN 1915, WeIss 1922). Of all species, about $38 \%$ species were phytophagous, mostly chrysomelids, followed by predaceous (about 33\%), and saprophagous (about $30 \%$ ) species.

The relative abundance was higher for Apion sp., Monolepta bifasciata (Hornstedt, 1788), Agrypnus sp. Colluris sp., Bledius sp., Scleron sp. and Stenus sp. while the species such as Altica unicolor (Olivier, 1808) and Caryedon sp. were least often collected.

On the basis of the species richness and abundance of coleopteran in the 24 monthly samples, the Shannon-Weaver diversity index $\left(\mathrm{H}^{\prime}\right)$ was between 1.17 and 3.44 , with a mean value of 3.11. The corresponding evenness values $\left(\mathrm{H}_{\text {even }}\right)$ was 0.65 and 0.85 with a mean value of 0.81 . However, the monthly
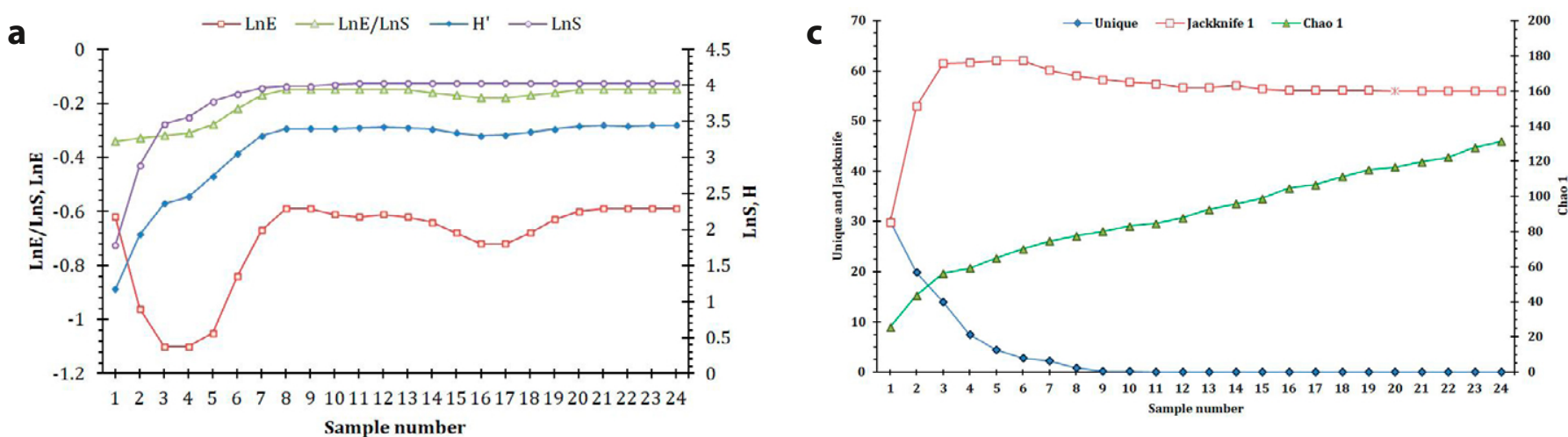

Figure 2. The SHE analysis [ $\mathrm{S}$ (species richness), $\mathrm{H}$ (information) and $\mathrm{E}$ (evenness) in the samples] (a), species richness $\mathrm{S}$, and abundance $\mathrm{N}$ (b), and various measures of species richness (Unique species, Chao1, and Jacknife1) (c), for Coleoptera, calculated on the data of 24 samples of different months from January, 2010 to December, 2011, in Bethuadahari Wildlife Sanctuary, West Bengal, India. The filled in triangles mark the sample where the species saturation was reached in the estimates in $\mathbf{b}$ and $\mathbf{c}$. 
beetle individuals in the samples and the species richness, the saturation was reached at the sample number 19 (Fig. 2), which is also reflected through the non-parametric measures of the species diversity such as Jackknife 1 (species saturation in 20th sample) (Fig. 2). The differences in the species richness among the samples were also reflected through the Chao 1 estimator, estimator of the unique and doubleton species in the samples. In comparison to the Chao 1, the Jackknife 1 estimate provided a better descriptor owing to similarity with the observed satura- tion of the species richness in the samples.

The discriminant function analysis indicates considerable differences in the relative representations of families of Coleoptera as shown in the biplot of Table. 3. The axes of the biplot explained about $87 \%$ of the variability of the data on the relative abundance of the coleopteran families. On comparison, the two families, Elateridae and Tenebrionidae, were oriented in different coordinates to rest of the families. The Fisher's distance among the pairs of the families remained significant for

Table 3. The results of Discriminant function analysis (DA) represented through the biplot (a), Eigen values (b) and the Fisher's distance among the different families of Coleoptera observed. (CARA: Carabidae, CERA: Cerambycidae, CHRY: Chrysomellidae, COCC: Coccinellidae, DYTI: Dytiscidae, ELAT: Elateridae, HYDR: Hydrophilidae, LAMP: Lampyridae, SCAR: Scarabaeidae, CURCU: Curculionidae, STAP: Staphylinidae, TENE: Tenebrionidae).

a. Biplot showing ordination of the Coleoptera families presented in centroids.

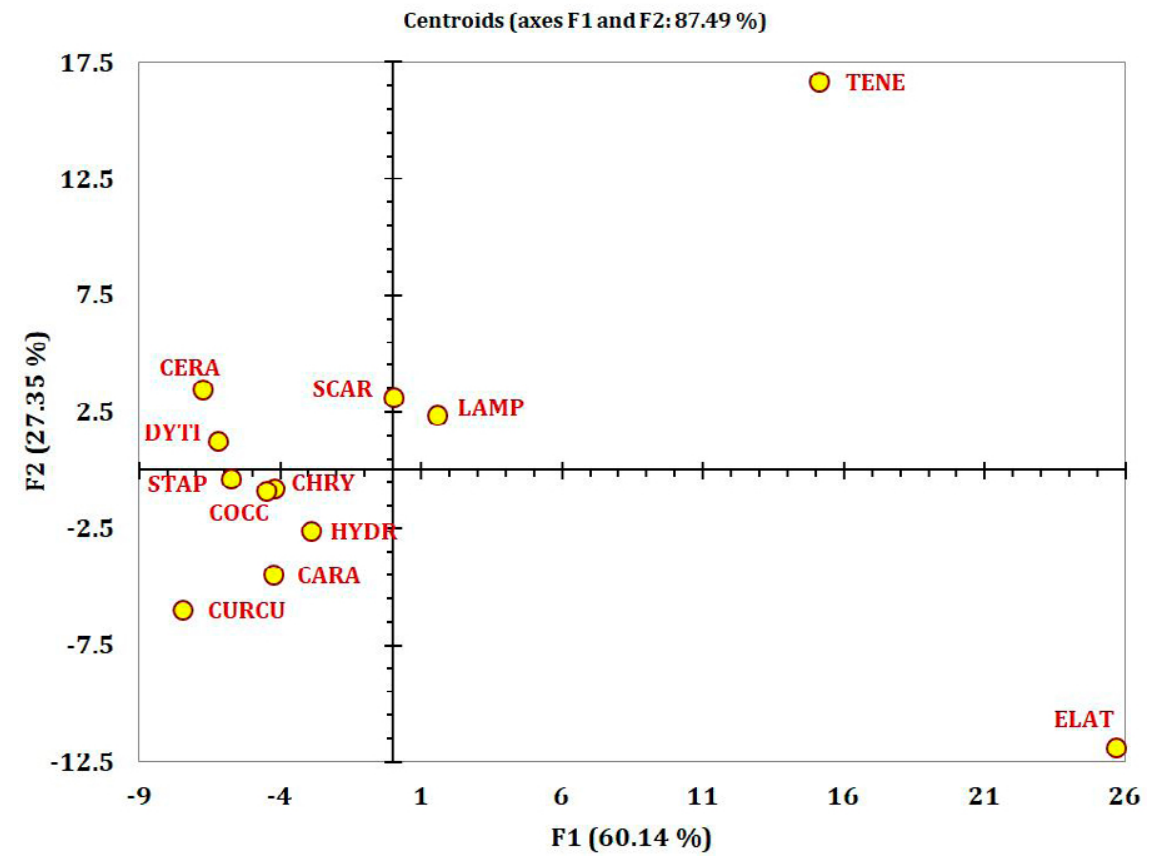

b. Eigen values of factors and canonical correlation coefficients.

\begin{tabular}{lccccc}
\hline Measures & F1 & F2 & F3 & F4 & F5 \\
\hline Eigen value & 120.2 & 54.7 & 15.1 & 2.871 & 2.468 \\
Discrimination (\%) & 60.1 & 27.4 & 7.557 & 1.437 & 1.235 \\
Cumulative \% & 60.1 & 87.5 & 95.1 & 96.5 & 9.031 \\
Canonical correlations function & 0.996 & 0.991 & 0.968 & 0.861 & 0.844 \\
\hline
\end{tabular}

c. Fisher's distance (significant values, $P<0.05$, are indicated in bold).

\begin{tabular}{|c|c|c|c|c|c|c|c|c|c|c|c|}
\hline & CARA & CERA & CHRY & cocc & DYTI & ELAT & HYDR & LAMP & SCAR & CURCU & STAP \\
\hline CERA & 8.01 & & & & & & & & & & \\
\hline CHRY & 3.03 & 2.91 & & & & & & & & & \\
\hline COCC & 2.7 & 2.73 & 0.5 & & & & & & & & \\
\hline DYTI & 4.25 & 1.92 & 0.72 & 0.83 & & & & & & & \\
\hline ELAT & 48.65 & 63.46 & 49.66 & 50.56 & 58.14 & & & & & & \\
\hline HYDR & 1.46 & 4.95 & 1.36 & 1.15 & 2.64 & 44.94 & & & & & \\
\hline SCAR & 11.47 & 4.79 & 4.59 & 5.2 & 4.9 & 45.3 & 6.98 & 5.91 & & & \\
\hline CURCU & 1.77 & 9.18 & 4.02 & 4.34 & 5.34 & 57.59 & 3.28 & 8.75 & 14.31 & & \\
\hline STAP & 2.8 & 3.2 & 0.38 & 0.74 & 0.79 & 54.98 & 1.71 & 4.05 & 5.85 & 3.67 & \\
\hline TENE & 40.39 & 35.62 & 34.33 & 35.08 & 35.47 & 46.76 & 34.57 & 20.2 & 26.82 & 50.34 & 36.48 \\
\hline
\end{tabular}


most of the cases reflecting the differences in the representation of the different species under the families.

\section{DISCUSSION}

Locally, terrestrial insect diversity depends on the resource availability and habitat, while climate determines diversity of insects and terrestrial arthropods, which is evident from biogeographical studies worldwide (BARBERENA-ARIAS \& Aide 2002, Deans et al. 2005, Hirao et al. 2007, Richards \& WINDSOR 2007). For example, about 1470 beetle species were recorded over a 4-year period in lowland tropical rainforests of Australia, but with a patchy distribution of species over time (GRIMBACHER \& STORK 2009). In comparison, 50 species of beetles belonging to 11 families recorded from mesic undisturbed tundra in Nunavut, Canada (ERnST \& BudDLE 2013). In tropical forests of Brazil, dung beetle assemblages vary between locations (21 species in Bahia, VIEIRA \& SILVA 2012; 33 species in Santa Catarina, CAmpos \& Hernández 2013) and are considerably greater than the present observation of just 3 species. In pine-dominated forests, VANDERWEL et al. (2006), found that xylophagous families Cerambycidae and Scolytidae were more abundant; in the present study, these families were represented by 4 species. The number of carabid species recorded (4 species) in the present study also is low compared to a study by ABDEL-DAYEM (2012) in Egypt (39 species in 28 genera). In Bandhavgarh National Park, Madhya Pradesh, India, a moist deciduous forest bordered with marsh and interspersed hillocks, is rich in beetles, with at least 44 scarabaeid species (CHANDRA \& AHIRWAR 2005). However, in terms of the number of species, the present observation ( 57 species) was greater than the 26 species recorded from deciduous forests of Achanakmar-Amarkantak Biosphere Reserve, central India (Chandra \& Gupta 2012) and the 12 species recorded from Melghat Tiger Reserve, Maharashtra, India (THAKARE \& ZADE 2012). In comparison to the tropical moist deciduous forests of Bethuadahari Wildlife Sanctuary, the steppe grasslands of Czech Republic appears to have a more diverse beetle assemblage with 103 being weevil (Curculionoidea), while rest were representatives of Anthribidae (4 species), Rhynchitidae (5 species), Apionidae (14 species) and Nanophyidae (1 species) (STEJSKAL 2004). From these comparisons, it is apparent that plant assemblages, landscapes, and climatic factors strongly influence beetle species richness. Apart from human-induced disturbance, the seasonal factors and resource availability in Bethuadahari Wildlife Sanctuary may cause variations in beetle abundance in the survey area. In Buxa National Park, West Bengal, high quality habitats in a mosaic of forest types account for a much greater richness of beetles (SARKAR et al. 2014, 2015a, 2015b).

The dynamics of plant succession and the resultant variations in the habitat complexity influences the insect species assemblages (Brown 1985). Such changes (BUSKIRK \& BusKIRK 1976, ARUN \& VIJAYAN 2004) may limit the spatial distribution and encounter in course of collection using the pitfall traps or sweep nets. The cryptic species residing in the litters and within the degrading woods may have been missed by the sampling methods used.
In moist deciduous forests, such as found in the Bethuadahari Wildlife Sanctuary, the depth of leaf litter, as well as the litter-dwelling invertebrate fauna, including coleopterans, varies with the seasons. The forest of the Bethuadahari Wildlife Sanctuary is dominated by Tectona grandis, which may account for less variability in the detritus on the forest floor. In a stable forest ecosystem, the availability of the detritus, including decaying wood and faecal matter of larger herbivores, are high in relation to live leaves. Although abundance of detritivore species of coleopterans was higher than the strictly phytophagous species, in general, the 2 groups varied in accordance with seasonal variations of the resources available. Among the coleopterans, the Scarabaeidae are relatively specialized detritus-associated taxa and involved in the decomposition process (ChitTenden 1915, WeIss 1922, WeINREICH 1968). The presence of scarabaeids accelerates litter decomposition and helps maintain soil quality (HALFFTER \& EDMONDS 1982, Hanski \& Cambefort 1991, Slade et al. 2007, Nichols et al. 2008, Simmons \& RidsDill-Smith 2011). The representatives of Staphylinidae, Tenebrionidae, and Elateridae, contribute to the multiple functional roles (MATTSON \& AdDy 1975, BROWN 1985, Schowalter 1995, Pfeiffer 1996, Dixon 2000, OMKar \& Pervez 2000, Basset et al. 2003, NAIR 2007) in sustaining the forest ecosystem. The ecological role of coleopteran and other insect groups in deciduous forests such as in Bethuadahari Wildlife Sanctuary may be better assessed by evaluating the trophic guild structure and the resources available over the entire season. Further studies would be beneficial to decipher interactions between the insect species and forest resources and sustaining the forest ecosystem.

\section{ACKNOWLEDGEMENTS}

We thank the two anonymous reviewers for their constructive comments on an earlier version of the manuscript. We are also grateful to the Director, Zoological Survey of India for providing the facilities and for his kind support and encouragement. The Department of Zoology, University of Calcutta, Kolkata provided the facilities, including DST-FIST, Government of India, in compilation of the manuscript. We thank the Scientists in the Coleoptera section, ZSI, for their kind help in confirmation of identification of specimens. PB acknowledges the scholarship provided by ZSI, Kolkata for undertaking this research.

\section{LITERATURE CITED}

Abdel-Dayem, M.S. 2012. An annotated checklist of the endemic Carabidae (Coleoptera) of Egypt. Check List 8: 197-203. https:// doi.org/10.15560/8.2.197

Andrewes, H. 1929. The fauna of British India, including Ceylon and Burma. Coleoptera: Carabidael. Carabinae. London: Taylor \& Francis. 431 pp. https://doi.org/10.5962/bhl.title.48423

Andrewes, H. 1935. The fauna of British India, including Ceylon and Burma. Coleoptera: Carabidae 2. Harpalinae. London: Taylor \& Francis. 323 pp. https://doi.org/10.5962/bhl.title.48423

Apigian, K. O., D. L. Dahlsten \& S. L. Stephens. 2006. Biodiversity of Coleoptera and the importance of habitat structural features in a Sierra Nevada mixed-conifer forest. Environmental Entomology 
35: 964-975. https://doi.org/10.1603/0046-225X-35.4.964

ARUN, P.R. \& V.S. VIJAYAN. 2004. Patterns in abundance and seasonality of insects in the Siruvani Forest of Western Ghats, Nilgiri Biosphere Reserve, southern India. The Scientific World Journal 4: 381-392. https://doi.org/10.1100/tsw.2004.33

Bambaradeniya, C. N. B., J. P. Edirisinghe, , D. N. De Silva, C. V. S. Gunatilleke, K. B. Ranawana \& S. Wijekoon. 2004. Biodiversity associated with an irrigated rice agro-ecosystem in Sri lanka. Biodiversity and Conservation 13: 1715-1753. http://doi.org/ d7xcw3

BARberena-Arias, M.F. \& T.M. Aide. 2002. Variation in species and trophic composition of insect communities in Puerto Rico. Biotropica 34: 357-367. https://doi.org/10.1111/j.1744-7429.2002. tb00549.x

Basset, Y., P. Hammond, H. Barrios, J. D. Holloway \& S. Miller. 2003. Vertical stratification of arthropod assemblages; pp. 17-27, in: Y. Basset, V. Novotny, S. Miller \& R.L. Kitching (eds.). Arthropods of Tropical Forests: spatio-temporal dynamics and resource use in the canopy. Cambridge: Cambridge University Press.

Brower, J.E., J.H. ZAR \& C.N. Ende. 1998. Field and laboratory methods for general ecology. 4th edition. Boston: McGraw-Hill. $273 \mathrm{pp}$.

BRown, V.K. 1985. Insect herbivores and plant succession. Oikos 44: 17-22.

BUSKIRK, R.E. \& W.H. BUSKIRK. 1976. Changes in arthropod abundance in a Highland Costa Rican Forest. American Midland Naturalist 95: 288-298.

CAmeron, M. 1930. The fauna of British India, including Ceylon and Burma. Coleoptera: Staphylinidae 1. (Micropeplinae, Oxytelinae, Oxyporinae, Megalopinae, Steninae, Enaesthetinae). London: Taylor \& Francis. 471 pp.

CAmeron, M. 1932. The fauna of British India, including Ceylon and Burma. Coleoptera: Staphylinidae 3. (Staphylininae, Trichophyinae, Termitodiscinae, Pygosteninae, Tachyporinae). London: Taylor \& Francis. 443 pp.

CAmeron, M. 1934. The fauna of British India, including Ceylon and Burma. Coleoptera: Staphylinidae. 2. (Paederinae). London: Taylor \& Francis. 257 pp.

CAmeron, M. 1939a. The fauna of British India, including Ceylon and Burma. Coleoptera: Staphylinidae 4. Part 1. Subfam. Pseudopernthinae and Aleocharinae (part). London: Taylor \& Francis. 430 pp.

Cameron, M. 1939b. The fauna of British India, including Ceylon and Burma. Coleoptera: Staphylindae 4. Part 2. Aleocharinae. London: Taylor \& Francis. 411-691 pp.

CAmpos, R. C. \& M.I.M. Hernández. 2013. Dung beetle assemblages (Coleoptera, Scarabaeinae) in Atlantic forest fragments in southern Brazil. Revista Brasileira de Entomologia 57: 47-51. https://doi. org/10.1590/S0085-56262013000100008

ChandRa, K. \& D. GuPTA. 2012. Diversity and relative abundance of pleurostict Scarabaeidae (Coleoptera) in Achanakmar-Amarkantak Biosphere Reserve, central India. World Journal of Zoology 7: 147-154. https://doi.org/10.5829/idosi.wjz.2012.7.2.63229

Chandra, K. \& S.C. AhiRwar. 2005. Scarabaeid beetles of Bandhavgarh National Park, Madhya Pradesh. Zoos' Print Journal 20: 1961-1964.

Chittenden, F.H. 1915. The violet rove-beetle (Apocellus sphaericollis Say). USDA Bulletin 264: 1-41.

Choste, P. M. 1999. Introduction to the identification of beetles (Coleoptera). Dichotomous keys to some families of Florida Coleoptera. Accessed at http://www.entnemdept.ufl.edu/choate/ beetles.pdf.

Chung, A.Y.C., P. Eggleton, M.R. Speight, P.M. Hammond \& V.K. CHEY. 2000. The diversity of beetle assemblages in different habitat types in Sabah, Malaysia. Bulletin of Entomological Research 90: 475-496. https://doi.org/10.1017/S0007485300000602
Crowson, R.A. 1956. Coleoptera: introduction and key to families. Handbooks for the identification of British insects. London: Royal Entomological Society of London. 59 pp.

Deans, A.M., J.R. Malcolm, S.M. Smith \& M.I. BellocQ. 2005. Edge effects and the responses of aerial insect assemblages to structural-retention harvesting in Canadian boreal peatland forests. Forest Ecology and Management 204: 249-266. http://doi. org/10.1016/j.foreco.2004.09.015

Dixon, A.F.G. 2000. Insect predator-prey dynamics. Ladybird beetles and biological control. Cambridge: Cambridge University Press. $257 \mathrm{pp}$.

ERnst, C.M. \& C.M. BudDLE. 2013. Seasonal patterns in the structure of epigeic beetle (Coleoptera) assemblages in two subarctic habitats in Nunavut, Canada. Canadian Entomologist 145: 171-183. http://doi.org/10.4039/tce.2012.111

Fowler, W. 1912. The fauna of British India, including Ceylon and Burma. Coleoptera: General introduction and Cicindelidae to Paussidae London: Taylor \& Francis. 529 pp.

GaHAN, C. 1906. The fauna of British India, including Ceylon and Burma. Coleoptera. Cerambycidae London: Taylor \& Francis. 329 pp.

GiLlot, C. 2005. Entomology. 3rd edition. Dordrecht: Springer. 832 pp.

Grimbacher, P.S. \& N.E. Stork. 2009. Seasonality of a diverse beetle assemblage inhabiting lowland tropical rain forest in Australia. Biotropica 41: 328-337. http://doi.org/10.1111/j.17447429.2008.00477.x

Gullan, P.J. \& P.S. Cranston. 1994. Insects: an outline of entomology. London: Chapman and Hall. 491 pp.

HaLFFTER, G. \& W.D. EDMONDS. 1982. The nesting behavior of dung beetles (Scarabaeinae): an ecological and evaluative approach. Mexico City: Man and the Biosphere Program UNESCO. 177 pp.

Halme, E. \& J. Niemelä. 1993. Carabid beetles in fragments of coniferous forets. Annales Zoologici Fennici 30: 17-30.

Hanski, I. \& Y. Cambefort. 1991. Dung beetle ecology. Princeton: Princeton University Press. 481 pp.

Hirao, T., M. Murakmi, A. Kashizaki \& S. Tanabe. 2007. Additive apportioning of lepidopteran and coleopteran species diversity across spatial and temporal scales in a cool-temperate deciduous forest of Japan. Ecological Entomology 32: 627-636. https://doi. org/10.1111/j.1365-2311.2007.00913.x

HURLBERT, S.H. 1984. Pseudoreplication and the design of ecological field experiments. Ecological Monographs 54: 187-211. https://doi. org $/ 10.2307 / 1942661$

JACOBY, M. 1908. The fauna of British India, including Ceylon and Burma. Coleoptera: Chrysomelidae 1. Eupodes, Camptosomes, Cyclica. London: Taylor \& Francis. 534 pp.

Joshi, P. C., K. Kumar \& M. ArYa. 2008. Assessment of insect diversity along an altitudinal gradient in Pinderi forests of Western Himalaya, India. Journal of Asia-Pacific Entomology 11: 5-11. http://doi.org/10.1016/j.aspen.2008.02.002

Krebs, C.J. 1999. Ecological methodology. Menlo Park: AddisonWesley Educational Publishers. 620 pp.

Kumar, S., M. Sankar, V. Sethuraman \& A. Musthakl. 2009. Population dynamics of white grubs (Coleoptera: Scarabaeidae) in the rose environment of northern Bangalore, India. Indian Journal of Science and Technology 2: 46-52.

Lee, S.J., J.D. Yeo \& H. Shin. 2008. Insect biogeography in the south-western sea of Korea with comments on the insect fauna of Kwanmae Island. Entomological Research 38: 165-173. http://doi. $\operatorname{org} / 10.1111 /$ j.1748-5967.2008.00155.x

Legendre, P. \& L.F.J. LegendRe. 1998. Numerical ecology. Amsterdam: Elsevier. 852 pp.

Losey, J.E. \& M. VAughan. 2006. The economic value of ecological services provided by Insects. BioScience 56: 311-323. http://doi. org/fw6h3v 
Losey, J.E. \& M. VAughan. 2008. Conserving the ecological services provided by insects. American Entomologist 54: 113-115. https:// doi.org/10.1093/ae/54.2.113

LuCKy, A., T.L. Erwin \& J.D. Witman. 2002. Temporal and spatial diversity and distribution of arboreal Carabidae (Coleoptera) in a Western Amazonian rain forest. Biotropica 34: 376-386. https:// doi.org/10.1111/j.1744-7429.2002.tb00551.x

ManLY, B.F.J. 1994. Multivariate statistical methods: a primer. 2nd edition. London: Chapman and Hall. 215 pp.

Marshall, G.A.K. 1916. The fauna of British India, including Ceylon and Burma. Coleoptera: Rhynchophora, Curculionidae London: Taylor \& Francis. 367 pp. https://doi.org/10.5962/bhl.title.9237

MatTsON, W.J. \& N.D. ADDY. 1975. Phytophagous insects as regulators of forest primary production. Science 190: 515-522. https://doi. org $/ 10.1126 /$ science. 190.4214 .515

MauliK, S. 1919. The fauna of British India, including Ceylon and Burma. Coleoptera: Chrysomelidae Volume 2. Hispinae and Cassidinae. London: Taylor \& Francis. 439 pp.

MauliK, S. 1926. The fauna of British India, including Ceylon and Burma. Coleoptera: Chrysomelidae Volume 3. Chrysomelinae and Halticinae. London: Taylor \& Francis. 442 pp.

Maulik, S. 1936. The fauna of British India, including Ceylon and Burma. Coleoptera: Chrysomelidae Volume 4. Galerucinae London: Taylor \& Francis. 648 pp.

McAleece, N., J. D. Gage, J. Lambshead \& G. L. J. Patterson. 1997. Biodiversity Professional software. The Natural History Museum $\&$ the Scottish Association for Marine Science. Accessed at http:// www.sams.ac.uk, 9 July 2013.

NAIR, K.S.S. 2007. Tropical forest insect pests: ecology, impact and management. Cambridge: Cambridge University Press.422 pp

Nichols, E., S. Spector, J. Louzada, T. Larsen, S. Amezquita \& M.E. FAVILA. 2008. Ecological functions and ecosystem services provided by Scarabaeinae dung beetles. Biological Conservation 141: 1461-1474. https://doi.org/10.1016/j.biocon.2008.04.011

Novotny, V. \& Y. BASSET. 2005. Host specificity of insect herbivores in tropical forests. Proceedings of the Royal Society of London 272: 1083-1090. https://doi.org/10.1098/rspb.2004.3023

Omkar \& A. Pervez. 2000. Biodiversity in predaceous coccinellids (Coleoptera: Coccinellidae) in India - a review. Journal of Aphidology 14: 41-66.

Petrova, V., Z. Čudare \& R. Cibulsskis. 2006. Predators and herbivores beetles (Coleoptera) naturally occurring on strawberry (Latvia). Acta Biologica Universitatis Daugavpiliensis 6: 155-159.

Pfeiffer, W. J. 1996. Litter invertebrates; pp. 137-181, in: D.P. ReAGAN \& R.B. WAIDE (eds.). The food web of a tropical rain forest. Chicago: University of Chicago Press.

RAMKRishna \& J.R.B. Alfred. 2007. Faunal resources in India. Kolkata: Zoological Survey of India. 427 pp.

RichARDS, L.A. \& D.M. WindSOR. 2007. Seasonal variation of arthropod abundance in gaps and the understory of a lowland moist forest in Panama. Journal of Tropical Ecology 23: 169-176. https:// doi.org/10.1017/S0266467406003907

Sabu, T.K., K.V. Vinod, M. Latha, S. Nithya \& J. Boby. 2011. Cloud forest dung beetles (Coleoptera: Scarabaeinae) in the Western Ghats, a global biodiversity hotspot in southwestern India. Tropical Conservation Science 4: 12-24. https://doi. org $/ 10.1177 / 194008291100400103$

Sarkar, S.K., S. SaHa \& D. Raychaudhuri. 2014. Taxonomic account of Dynastinae fauna (Coleoptera: Scarabaeidae) of Buxa Tiger Reserve (West Bengal, India). Romanian Journal of Biology, Zoology 59: 89-111.

SARKar, S.K., S. Saha \& D. Raychaudhuri. 2015a. Click beetle diversity of Buxa Tiger Reserve, West Bengal, India. World Scientific News 19: 120-132.
SARKar, S.K., S. SAHA \& D. RaYchaudhuri. 2015b. On the taxonomy of Scarabaeine fauna (Coleoptera: Scarabaeidae) of Buxa Tiger Reserve (BTR), West Bengal, India. Munis Entomology \& Zoology 10: 18-48.

Sarooshi, R.A., D.R. Blundell \& D. L. Peasley. 1979. Blemishes and abnormalities of avocado fruit. Agricultural Gazette of New South Wales 90: 18-20.

SCHOWALTER, T.D. 1995. Canopy invertebrate community response to disturbance and consequences of herbivory in temperate and tropical forests. Selbyana 16: 41-48.

Schowalter, T.D., W.W. Hargrove \& D.A. Crossley, JR. 1986. Herbivory in forested ecosystems. Annual Review of Entomology 31: 177-196.

SilfverberG, H. 1989. Chrysomelidae; pp. 267-270, in: C.H. Scholtz \& E. Holm (eds.). Insects of Southern Africa. Durban: Butterworths.

Simmons, L.W. \& J. RidSDiLL-Smith. 2011. Ecology and evolution of dung beetles. Oxford: Wiley-Blackwell. 368 pp.

Slade, E.M., D.J. Mann, J.F. Villanueva \& O.T. Lewis. 2007. Experimental evidence for the effects of dung beetle functional group richness and composition on ecosystem function in a tropical forest. Journal of Animal Ecology 76: 1094-1104. https://doi. org/10.1111/j.1365-2656.2007.01296.x

StejSKAL, R. 2004. Contribution to the knowledge of beetles (Coleoptera) of dry grasslands - weevils (Curculionoidea) of Ječmeniště near Znojmo (Southern Moravia). Entomofauna Carpathica 16: $74-82$.

Taboada, Á., R. Tárrega, L. Calvo, E. Marcos, J.A. Marcos \& J.M. SAlgado. 2010. Plant and carabid beetle species diversity in relation to forest type and structural heterogeneity. European Journal of Forest Research 129: 31-45. https://doi.org/10.1007/ s10342-008-0245-3

ThaKare, V.G. \& V.S. ZADE. 2012. Diversity of beetles (Insecta: Coleoptera) from the vicinity of Semadoh-Makhala road, Sipna range, Melghat tiger reserve, (M.S.) India. Bioscience Discovery 3: $112-115$.

Vanderwel, M.C., J.R. Malcolm, S.M. Smith \& N. Islam. 2006. Insect community composition and trophic guild structure in decaying logs from eastern Canadian pine-dominated forests. Forest Ecology and Management 225: 190-199. https://doi. org/10.1016/j.foreco.2005.12.051

VieirA, L. \& F.A.B. Silva. 2012. Dung beetles (Coleoptera: Scarabaeidae: Scarabaeinae) of the Floresta Nacional Contendas do Sincorá, Bahia, Brazil. Check List 8: 733-739. https://doi. org/10.15560/8.4.733

WeINREICH, E. 1968. Über den Klebfangapparat der Imagines von Stenus Latr. (Coleoptera, Staphylinidae) mit einem Beitrag zur Kenntnis der Jugendstadien dieser Gattung. Zeitschrift für Morphologie der Tiere 62: 162-210.

Weiss, H.B. 1922. A summary of the food habits of North American Coleoptera. American Naturalist 56: 159-164.

Authors' contributions: The research work was conceived by PB and AKS; field studies contributed by $\mathrm{PB}$, and manuscript preparation, data analysis and interpretation carried out by PB and GA. This is a part of the Ph.D. dissertation of PB, carried out as a research fellow of ZSI, Kolkata, from the University of Kalyani, West Bengal, India.

Received: 15 October 2015

Accepted: 30 April 2017

Academic editor: Juan Pablo Botero 